\title{
The Labour Supply of Female Engineers in Germany
}

\author{
Eva Schlenker \\ University of Hohenheim, Stuttgart
}

\begin{abstract}
Recent developments in the German demography will give rise to a shortage in skilled workers in the coming decades. A solution to this problem might involve a higher degree of integration of female engineers in the workforce. Data from the German microcensus 2006 confirm the existence of a hidden reserve of female engineers. Ordered response models are used to show that the labour supply in the engineering sector is mainly determined by age. In addition, the labour supply of female engineers depends on their number of children, and on the age of the youngest child.
\end{abstract}

Keywords: Female Labour Supply, Ordered Probit, Demographic Change.

\section{Introduction}

Due to demographic changes the German economy lacks skilled workers. That development hits mainly the vocational field of technology and engineering (see Koppel, 2008a, p. 91). Already today, the society looses prosperity due to missing engineers and politicians are looking for solutions. One approach might be a better integration of female workers in general into the German labour market. This approach seems to be promising comparing the labour supply of women, mothers in particular, in Germany with many other OECD-countries. In 2006, the share of women who were integrated in the labour market was $61.5 \%$ in Germany, in Denmark the share of working women was $73.2 \%$, in Austria $63.5 \%$, and in the USA 66.1\% (see Institut der deutschen Wirtschaft Köln (ed.), 2008, p. 135). Hence, there might also exist a reserve of female engineers who are not active members of the labour market. ${ }^{1}$

Female labour supply was intensively analysed during the last decades (see i.a. Strøm and Wagenhals, 1991; Uunk, Kalmijn, and Muffels, 2005; Vogel, 2007). The main results, however, have not changed since the first studies were published during the sixties: Women - in contrast to men - split their time not only between work and leisure. Housework and looking after children is their third occupation (see Mincer, 1962, p. 65). As women take into account the possibility of spending less time working after marriage and motherhood they invest less into their education and, therefore, - according to the theory of human capital - women have lower opportunity costs, if they specialise in housework. The households gain from the division of labour:

,Even if the process continued until married women no longer had primary responsibility for child care and other housework, married households would still greatly gain from a division of labor in the allocation of time and investments [...]" (Becker, 1985, p. 55)

\footnotetext{
${ }^{1}$ It has to be noted, that the German labour market is strongly horizontally segregated, for example, only one-fifth of the students in technology, sciences, mathematics and computing was female during the winter term 2007/08 (see Statistisches Bundesamt, 2008, p. 14
} 
In sociology the low labour supply of women in Germany is explained by the "model of the male breadwinner" (Wimbauer, Henninger, and Gottwald, 2007, p. 33). Due to socialisation the predominant gender roles and the according schedules of responsibilities are deeply tied into the German society: As men are responsible for earnings, women care for children and housework. During the last years this traditional model of family has changed and higher educated women have entered the labour market to a larger extent (see Holst, 2000, p. 68). The degree the labour market of engineers is still characterised by the "male breadwinners" will be analysed in the following sections.

The article is structured as follows: Section 2 illustrates the dataset used for the study. Important variables are defined and the dataset is screened for descriptive results. This paragraph motivates Section 3 where the data is examined by ordered probit models. The main determinants of the labour supply of engineers are detected. Based on these results, the number of engineers who are not integrated in the labour market is estimated. Finally, Section 4 concludes.

\section{Data and Methods}

\subsection{Data Sources and Variables}

The study at hand is based on the German microcensus 2006. The microcensus is an official survey which covers a representative $1 \%$-sample of the German population. With 820000 interviewees, the microcensus is the only sample that is huge enough to extract a subsample of engineers of adequate size. For the examination the dataset is filtered. The subsample includes people holding a degree in engineering who are younger than 56 year and excludes engineers who work not at all or part-time for other reasons, e.g. education and/or health problems. The completed subsample finally comprises 10105 engineers of which 1542 are women.

The number of hours worked per week is not available in the German microcensus. Therefore, for the subject of interest the variable "employment" is constructed, that differentiates between not in labour force (1), part-time (2) and fulltime (3). For a full description of all variables see Table 1 .

As independent variables a dummy variable controls for the difference between East and West Germany. Other dummy variables are introduced for age groups. That classification is used instead of a metric approach for distinguishing between different periods of life.

Beside these sociodemographic variables several independent variables for the family background of each engineer are regarded. The number of children under 18 years living in the same household is examined as well as dummy variables for the age of the youngest child in that household, the marital status and the partner's net income.

\subsection{Model Selection}

Labour supply is not measured by a continuous and fully observable variable in the microcensus, the variable "employment" is used as dependent variable. As the range of 
Table 1: Description of variables.

\begin{tabular}{ll}
\hline Variable & Description \\
\hline employment & degree of employment, not in labour force (1), part-time job (2), fulltime job (3) \\
age1 & 30 years or younger $(1)$ \\
age2 & from 31 years till 45 years $(1)$ (reference) \\
age3 & 46 years or older $(1)$ \\
income0 & partner does not have any income $(1)$ (reference) \\
income1 & monthly partner's net income till $500 €(1)$ \\
income2 & monthly partner's net income above $500 €$ till $1100 €(1)$ \\
income3 & monthly partner's net income above $1100 €$ till $5000 €(1)$ \\
income2 & monthly partner's net income above $5000 €(1)$ \\
east & residence in East Germany (1) \\
married & marital status: married (1) \\
childrenU18 & number of unmarried children younger 18 years living in the same household \\
benjamin3 & age of the youngest child in the family 3 years or younger $(1)$ \\
benjamin6 & age of the youngest child in the family between 4 and 6 years $(1)$ \\
benjamin10 & age of the youngest child in the family between 7 and 10 years $(1)$ \\
\hline
\end{tabular}

the variable is limited, classical linear models are not suitable for the explanation of employment behaviour. The variety of the dependent variable is constrained and, thus, only models of discrete choice can be used. Since the levels for employment have a natural order, numerical values are given to the outcomes (see Section 2.1) that reflect the ranking of the outcomes and are ordinal. Therefore, ordered choice models will be used in the following.

Ordered choice models are based on the idea of a "sentiment" about how people feel concerning the alternative choices. That unobservable "sentiment" enters decisions as a latent variable $y^{*}$. Economic theory suggests certain factors to have an impact on that latent variable, namely the preference for different degrees of employment. The choice observed is due to a comparison of the latent variable, the "sentiment" towards a higher degree of employment, and relative thresholds that separate the observable outcomes, the degrees of employment.

$$
\text { employment }= \begin{cases}1 \text { (not in labour force) } & \text { if } y^{*} \leq \alpha_{1} \\ 2 \text { (part-time) } & \text { if } \alpha_{1}<y^{*} \leq \alpha_{2} \\ 3 \text { (fulltime) } & \text { if } y^{*}>\alpha_{2}\end{cases}
$$

For representing these outcomes an assumption concerning the probability distribution of $y^{*}$ is needed. The assumption of a standard normal distribution defines an ordered probit model. If the latent variable $y^{*}$ is assumed to be a logistic random variable, ordered logit models are the results. Both model types are quite similar. For the study at hand, ordered probit models are used because of their greater popularity in econometrics.

The estimation of ordered choice models is by maximum likelihood (ML). ${ }^{2}$ The estimation of ordered choice models is already existing routine in statistical software. The

\footnotetext{
${ }^{2}$ For further details see Aitchison and Silvey (1957).
} 
study at hand uses the software Stata for all further calculations and concentrates on ordered probit models for modelling the labour supply. As several studies support different employment patterns for men, single women and women living together with a partner, these three groups are also separated in the study at hand (see Holst, 2000).

\subsection{A Descriptive Look at the Data}

The completed dataset comprises 10105 engineers, 1542 of these engineers are female. A closer look at their degrees of employment already shows different patterns of employment between male and female engineers (see Table 2). The percentage of male engineers who are fulltime employees adds up to $93 \%$, around $3 \%$ of them work part-time and additional $4 \%$ are not employed at all. The female pattern looks different: Only around $65 \%$ of the female engineers in Germany work fulltime, $13 \%$ are not in labour force. Part-time employment accounts for $23 \%$ of the 1542 females in the dataset. One implication of these job patterns is, that part-time jobs in engineering are female dominated. Around $60 \%$ of the part-time working engineers are women, even if only around $11 \%$ of the employed engineers in Germany are women (see Koppel, 2008b, p. 7).

Table 2: Status of labour supply according to sex and number of children.

\begin{tabular}{lccc}
\hline Number of children & \multicolumn{3}{c}{ status of employment } \\
younger than 18 years & not in labour force & in part-time & in fulltime \\
\hline men & $\mathbf{3 6 3}$ & $\mathbf{2 3 0}$ & $\mathbf{7 9 7 0}$ \\
no children & 251 & 138 & 4431 \\
one child & 55 & 37 & 1503 \\
two children & 44 & 43 & 1631 \\
three children or more & 13 & 12 & 405 \\
\hline women & $\mathbf{1 9 5}$ & $\mathbf{3 5 3}$ & $\mathbf{9 9 4}$ \\
no children & 98 & 119 & 738 \\
one child & 44 & 110 & 172 \\
two children & 44 & 105 & 75 \\
three children or more & 9 & 19 & 9 \\
\hline Pearson $\chi^{2}:(226.28)^{* * *}$ & \multicolumn{4}{|}{} \\
\hline Microcensus 2006, own calculation. & &
\end{tabular}

Table 2 also reveals gender differences according to children. Three out of four female engineers without children work fulltime. Only $42 \%$ of mothers are in fulltime employment. Their share of part-time work accounts to $40 \%$. In comparison, nine out of ten male engineers who do not live with children work fulltime. This share even increases to $95 \%$ with fatherhood. The share of part-time working fathers living with their children is smaller than $3 \%$. The descriptive exploration of the dataset already shows that the labour supply of female and male engineers differs to a large extent. In the following, the behaviour at the labour market is investigated by ordered probit models. 
Table 3: Estimation results for ordered probit models. Standard deviation are given in parentheses, $* * *$ stands for significant at a $1 \%$-level (own calculations).

\section{Ordered Probit Model}

\begin{tabular}{lrrr} 
Variable & \multicolumn{2}{c}{ Women living } & \multicolumn{1}{c}{ Men } \\
& with a partner & without a partner & \\
\hline east & $0.205^{* * *}(0.008)$ & $0.368^{* * *}(0.014)$ & $-0.229^{* * *}(0.005)$ \\
age1 & $0.164^{* * *}(0.016)$ & $-0.102^{* * *}(0.017)$ & $0.047^{* * *}(0.007)$ \\
age3 & $-0.176^{* * *}(0.009)$ & $-0.686^{* * *}(0.014)$ & $-0.295^{* * *}(0.004)$ \\
childrenU18 & $-0.289^{* * *}(0.006)$ & $-0.531^{* * *}(0.011)$ & $0.016^{* * *}(0.003)$ \\
income1 & $-0.853^{* * *}(0.032)$ & & $-0.148^{* * *}(0.006)$ \\
income2 & $-0.777^{* * *}(0.030)$ & & $0.032^{* * *}(0.006)$ \\
income3 & $-0.541^{* * *}(0.029)$ & & $0.053^{* * *}(0.005)$ \\
income4 & $-0.648^{* * *}(0.032)$ & & $-0.362^{* * *}(0.027)$ \\
benjamin3 & $-0.271^{* * *}(0.013)$ & $-0.659^{* * *}(0.031)$ & $-0.066^{* * *}(0.008)$ \\
benjamin6 & $-0.367^{* * *}(0.014)$ & $-0.280^{* * *}(0.042)$ & $-0.296^{* * *}(0.009)$ \\
benjamin10 & $-0.219^{* * *}(0.015)$ & $0.231^{* * *}(0.029)$ & $0.124^{* * *}(0.010)$ \\
married & $-0.501^{* * *}(0.012)$ & & $0.363^{* * *}(0.005)$ \\
\hline pseudo- $R^{2}$ & 0.0694 & 0.0832 & 0.0235 \\
LR-Test $\chi^{2}$ & $15791.61 * * *$ & $6440.00^{* * *}$ & $15283.22 * * *$ \\
\hline
\end{tabular}

\section{Results of the Ordered Probit Models}

\subsection{The Determinants of Labour Supply in Engineering}

The results of the ordered probit models are shown in Table 3. A closer look at the average partial effects confirms the results from Section 2.3 (see Table 5 in the Appendix). An increasing number of children reduces the probability of a female engineer to work fulltime, while it increases the probability to work part-time or not to be in labour force. These effects are stronger for women living without a partner than for married women or woman who live together with their partners. In contrast to that, fatherhood even raises the probability for fulltime employment. The same pattern can be seen for the marital status: Marriage decreases the probability of a women to be in fulltime employment, whereas married male engineers have a higher probability for a fulltime job than their unmarried colleagues (see Table 5).

The hypothesis that mothers of younger children work less because small children need more care is proven by the results, too, since the probability for parents of small children to work fulltime is smaller than for engineers in families without small children. There are also differences between single mothers and mothers who bring up their children with a partner: The probability of a single mother to return to fulltime employment after their children enter primary school increases (see variable benjamin10 in Table 5), while mothers with a partner still stay at home. The average partial effects also expose differences between the former German Democratic Republic and Western Germany. In Eastern Germany female engineers have higher probabilities for working fulltime than women in Western Germany, for male engineers the opposite is true. These results are consistent with other studies that differences still do exist between these regions. That 
can be explained by different family policies of the two former states: As the Federal Republic of Germany was dominated by the "male breadwinner model", the family policy of the former German Democratic Republic promoted the family model with two working parents. Unfortunately, no clear statement can be made from the results concerning partner's net income.

There are, however, not only differences between male and female engineers. The most important determinant of the labour supply behaviour of engineers in general is age. Engineers who are 30 years or younger have significantly higher probabilities to work fulltime, while the probability of fulltime employment decreases rapidly for engineers aged 46 years or older (see Table 3). However, it is not shown here, if older engineers decide voluntarily to work less. Another reason might be that companies prefer to engage young engineers who have just finished university (see e.g. Zentrum für Europäische Wirtschaftsforschung, 2004, p. 10).

\subsection{How Many Additional Engineers Do Exist?}

After having revealed the determinants of labour supply in engineering it can be assessed whether the employment of women might offer a strategy for companies to overcome the shortage of skilled labour. Therefore, the extent of engineers who are not (fully) integrated in the labour market is estimated based on the ML estimation. These calculations are based on the ordered probit models discussed in Section 3.1. In a first step, individual probabilities for the status of labour supply are estimated for all engineers in the dataset by using Stata. Thereupon, the probabilities are averaged for each of the three groups and extrapolated to the total number of persons in each groups (see Table 4). The total number is computed by weights available in the microcensus.

Table 4: Estimated workforce in engineering. Estimated probabilities in parentheses. Own calculations, rounded off hundreds and per cent.

\begin{tabular}{lccc}
\hline Group & $\begin{array}{c}\text { estimated number } \\
\text { not in labour force }\end{array}$ & $\begin{array}{c}\text { estimated number } \\
\text { part-time }\end{array}$ & $\begin{array}{c}\text { estimated number } \\
\text { fulltime }\end{array}$ \\
\hline female engineers & 18800 & 33800 & 73800 \\
living together with a partner & $(15 \%)$ & $(27 \%)$ & $(59 \%)$ \\
\hline female engineers & 5600 & 6700 & 43600 \\
living without a partner & $(10 \%)$ & $(12 \%)$ & $(78 \%)$ \\
\hline male & 51600 & 30900 & 959400 \\
engineers & $(5 \%)$ & $(3 \%)$ & $(93 \%)$ \\
\hline total & 76000 & 71400 & 1076800 \\
\hline
\end{tabular}

The idea of a reserve of female engineers can be generally adopted. Estimated 24400 women who graduated in engineering are not in labour force, additional 40500 female engineers work part-time. However, the majority of the unused workforce is male. The estimated number of male engineers who are not in labour force is 51600 and 30900 engineers work part-time. These last two groups might possibly be older engineers. In general, it can be stated that the importance of female engineers in the unused workforce 
is extremely higher than in engineering in general. Nearly six out of ten engineers who work part-time and $32 \%$ of all engineers not in labour force are women. In total, $44 \%$ of the reserve in workforce are female engineers. Compared to the general importance of women in engineering this share is nearly four times higher. However, women are still the minority and the extent of the unused workforce is small in comparison to the need (see Koppel, 2008b, p. 21) and, therefore, the recruiting of already educated female German engineers will not be a sufficient solution.

\section{Conclusion}

The demographic development will change the labour market in Germany. Already today, there exists a lack of engineers. For a country whose economy is built on engineering in general and automotive engineering in particular, wealth and economic growth depends on the availability of highly educated engineers. Thus, German politicians are looking for solutions. One idea might be a better integration of women into the labour market.

The study at hand analysed the labour supply of female engineers based on the microcensus 2006. The descriptive examination of the dataset in Section 2.3 shows that the patterns of labour supply are gender specific. Furthermore, it can be shown that the share of women who work part-time is more than seven times higher than the share for men. In Section 3, ordered probit models are estimated for the labour supply in engineering. For this purpose, the sample is divided into three different groups: male engineers, female engineers living together with a partner and female engineers who do not live with a partner. The results show different patterns of labour supply between these groups: For women who graduated in engineering the probability to work fulltime decreases with the number of children in the household, while their male colleagues do not reduce employment with fatherhood. The models also reveal differences between East and West Germany: As the probability for fulltime employment is higher for women in the eastern part of the country, it is smaller for men in Eastern Germany.

However, the results of the models expose that for all engineers employment behaviour is highly determined by age. Older engineers are less integrated in the labour market, their probabilities to work part-time or to be not in the workforce are significantly higher than for younger engineers. Though, the data do not show if that pattern is implied by the engineers themselves or by companies that prefer to employ young engineers (see Zentrum für Europäische Wirtschaftsforschung, 2004). Based on the ordered probit models, the number of engineers who are not or part-time employed is estimated. The results show that 71400 engineers work part-time, 40500 of them are female. Additional 76000 engineers are not in labour force, $32 \%$ of them are women. Nearly 1.1 million engineers works fulltime according to the estimations.

In conclusion, a better integration of (already educated) female engineers in the labour market is no exclusive solution to the problem of labour shortage. All in all, it is shown by the data that the reserve of engineers in general is small and the number of these engineers will be insufficient to occupy all free jobs (compare Table 4 and Koppel, 2008a, p. 91). In order to solve this problem, a great number of policies are necessary in the fields of education and immigration. To increase the number of students, in particular female ones, 
in engineering is one example for such a policy. An other might be an extended system of on-job education for older engineers for increasing their employment rates. All these actions will need monetary and personal commitment of politics and companies, alike.

\section{Appendix}

Table 5: Average partial effects of the ordered probit models. Standard deviation are given in parentheses, ${ }^{* *}$ stands for significant at a $1 \%$-level (own calculations).

\begin{tabular}{|c|c|c|c|}
\hline \multirow{3}{*}{ Variable } & \multicolumn{3}{|c|}{ Ordereed Probit Model } \\
\hline & \multicolumn{2}{|c|}{ Women living } & \multirow[t]{2}{*}{ Men } \\
\hline & with a partner & without a partner & \\
\hline fulltime & & & \\
\hline east & $0.00318 * * *(0.00016)$ & $0.06567 * * *(0.00314)$ & $-0.03607 * * *(0.00063)$ \\
\hline age 1 & $0.00264 * * *(0.00030)$ & $-0.01595^{* * *}(0.00250)$ & $0.00834 * * *(0.00124)$ \\
\hline age 3 & $-0.00238^{* * *}(0.00010)$ & $-0.09389 * * *(0.00152)$ & $-0.04845^{* * *}(0.00062)$ \\
\hline childrenU18 & $-0.00437 * * *(0.00012)$ & $-0.08768 * * *(0.00221)$ & $0.00274 * * *(0.00055)$ \\
\hline income 1 & $-0.00585^{* * *}(0.00011)$ & & $-0.02401 * * *(0.00092)$ \\
\hline income 2 & $-0.00714 * * *(0.00014)$ & & $0.00561 * * *(0.00108)$ \\
\hline income 3 & $-0.01253^{* * *}(0.00038)$ & & $0.00939 * * *(0.00094)$ \\
\hline income4 & $-0.00506^{* * *}(0.00013)$ & & $-0.04986^{* * *}(0.00281)$ \\
\hline benjamin3 & $-0.00293 * * *(0.00011)$ & $-0.07043 * * *(0.00203)$ & $-0.01108 * * *(0.00128)$ \\
\hline benjamin6 & $-0.00354 * * *(0.00010)$ & $-0.03793 * * *(0.00466)$ & $-0.04382 * * *(0.00106)$ \\
\hline benjamin 10 & $-0.00246^{* * *}(0.00013)$ & $0.04216^{* * *}(0.00610)$ & $0.02294 * * *(0.00191)$ \\
\hline married & $-0.00947 * * *(0.00017)$ & & $0.05856^{* * *}(0.00107)$ \\
\hline
\end{tabular}

\section{References}

Aitchison, J., and Silvey, S. (1957). The generalization of probit analysis to the case of multiple responses. Biometrika, 44, 131-140.

Becker, G. S. (1985). Human capital effort, and the sexual division of labor. Journal of Labor Economics, 3, S33-S58.

Holst, E. (2000). Die Stille Reserve am Arbeitsmarkt: Größe - Zusammensetzung Verhalten. Berlin: Ed. Sigma.

Institut der deutschen Wirtschaft Köln (ed.). (2008). Deutschland in Zahlen 2008. Köln: Deutscher Instituts-Verlag.

Koppel, O. (2008a). Ingenieurarbeitsmarkt in Deutschland - gesamtwirtschaftliches Stellenangebot und regionale Fachkräftelücken. IW-Trends, 35, 81-95.

Koppel, O. (2008b). Ingenieurlücke in Deutschland - Ausmaß, Wertschöpfungsverluste und Strategien. http://www.techfak.uni-erlangen.de/beschaeftigte/ pdf/ingenieurluecke.pdf. (Downloaded: 08/20/2009)

Mincer, J. (1962). Labor force participation of married women: A study of labor supply (Tech. Rep.). Aspects of Labor Economics. A Report of the National Bureau of 
Economic research. Princeton/N.J.: Universities. National Bureau Committee of Economic Research.

Statistisches Bundesamt (Ed.). (2008). Bildung und Kultur - Studierende an Hochschulen Wintersemester 2007/08. Bonn: Fachserie 11 Reihe 4.1.

Strøm, S., and Wagenhals, G. (1991). Female labour supply in the Federal Republic of Germany. Jahrbuch für Nationalökonomie und Statistik, 208, 575-595.

Uunk, W., Kalmijn, M., and Muffels, R. (2005). The impact of children on women's labour supply: A reassessment of institutional effects in Europe. Sociological Problems, 48, 41-62.

Vogel, A. (2007). Determinanten der Frauenerwerbstätigkeit im Haushaltskontext. Wirtschaft und Statistik, 3, 312-319.

Wimbauer, C., Henninger, A., and Gottwald, M. (2007). „Liebe”, Arbeit, Anerkennung - (Un-)Gleichheit in Doppelkarriere-Paaren. In C. Wimbauer, A. Henninger, and M. Gottwald (Eds.), Die Gesellschaft als, ,institutionalisierte Anerkennungsordnung" - Anerkennung und Ungleichheit in Paarbeziehung, Arbeitsorganisationen und Sozialstaat (p. 33-67). Opladen: Verlag Barbara Budrich.

Zentrum für Europäische Wirtschaftsforschung (Ed.). (2004). Fachkräftemangel bei Ingenieuren. ftp://ftp.zew.de/pub/zew-docs/gutachten/VDIstudie.pdf. (Downloaded: 07/26/2008)

Author's address:

Eva Schlenker

University of Hohenheim

Statistics and Econometrics (520B)

Schloss, Osthof West 123

70593 Stuttgart

Germany

E-mail: Eva.Schlenker@uni-hohenheim.de 